\title{
AFTER THE WAR AND REPRESSIONS: MEDIATING OF TRAUMATIC EXPERIENCES IN ESTONIAN LIFE STORIES
}

\author{
Tiiu Jaago \\ Associate Professor \\ Department of Estonian and Comparative Folklore \\ Institute of Cultural Research, University of Tartu, Estonia \\ tiiu.jaago@ut.ee
}

\begin{abstract}
This article looks at how contemporary life stories reflect the historicalpolitical events that took place in the $1940 \mathrm{~s}$, and their impact on the development of family relationships. The focus is on the expression of traumatic experiences caused by these events. Observable events, such as the Second World War, living under a foreign power, political repressions, escape to the West, etc., and their impact on Estonian society have been analysed by Estonian sociologists using the concept of cultural trauma. Literary researchers have studied this subject from the perspective of literary trauma theory. This article provides an analysis of Estonian life stories, which is based on the tools of folkloristic narrative research and the trauma conception. Although the narrators do not use the word 'trauma', it can be assumed that they express their traumatic experiences in some special way. It appears, for instance, that these first-person narratives provide a laconic description of the situation, relatively free of the emotion that possessed the narrator in the situation being described. The narrative style is determined by the distance between the narrator and the event that traumatizes them. This distance can be created by the narrator through using urban legends and rumours to characterize the general attitudes of the period being described. When the events of the twentieth century were discussed in the stories told in the 1990s, the dynamics of family relationships between two or three generations came to the fore in the stories told in the present time. The changing focus of the stories, shifting from events to the subject of intimacy, directs researchers to observe the transmission and transformation of trauma in a new context.
\end{abstract}

Keywords: family relationships, life story, rumours, traumatic experience

This article looks at how events relating to the Second World War and the establishment of the Soviet regime in Estonia, and their effects, are conveyed in life stories narrated at the end of the twentieth and the beginning of the twenty-first centuries. The source material for the analysis comes from the 
Estonian Life Stories Collection (EKLA 350). Interview materials received from life story narrators and their descendants are also used (MK).

Thematic focal points in life story narrations have shifted during the decades under study. Stories narrated during the 1990s mostly describe how the upheaval caused by the historical-political events of the 1940s changed people's lives. Thereafter, narrators began to concern themselves more with describing close relations. In this article the focus is laid mainly on one aspect of the observed life stories: how the narrators mediate their traumatic experiences. The main question is: how is the traumatic experience of those caught up in the historical-political events of the 1940s transforming and emerging before us in the late twentieth and early twenty-first centuries? Although the narrators do not use the central concepts of trauma theory, such as being a victim of violence, moral responsibility, or asking for and granting forgiveness (see, e.g., Meek 2015: 6), one cannot claim that they have no traumatic experience. Hence it is important to ask how narrators in their life stories, as a kind of a particular genre, report their traumatic experiences.

To consider the above more closely, a general background of narrations used for the source data, as well as the researcher's starting position in delineating trauma in a life story, are introduced in the first part of this article. The second part of the article offers an analysis of life stories.

\section{SOURCE MATERIAL: THE LIFE STORIES}

In the 1990s, cultural researchers asked the people of Estonia to write down their life stories and send them to the Estonian Literary Museum. The impetus needed to tell these stories was provided through collection campaigns that had what could be called rather vague titles, such as "Do you remember your life history?" (1989) and "Women speak" (1995). Especially popular were topics that encouraged the narration of events in the recent past, such as "My destiny and the destiny of those close to me in the labyrinth of history" (1996-1997), and "My life and the life of my family in the Estonian SSR and the Estonian Republic" (2000). Whereas the former collection campaigns received 50 to 60 contributions, the latter, historically-minded collection campaigns collected 262 and 330 life stories respectively (Hinrikus \& Kõresaar 2004: 21-25). This collection work has continued up to the present and has now grown into the Estonian Life Stories Collection, containing upwards of 3,500 original handwritten life story narrations (EKLA 350). 
One reason for the life story collection initiative was the conflict between Estonian and Soviet approaches to history; namely, there were several topics that were not brought up in Soviet approaches. This concerned, first and foremost, Estonia's national independence (1918-1940), the mass repressions of 1941 and 1949, and the mobilization of Estonian youth into the occupying army, or fleeing the Red Army and joining the Finnish army, for example. ${ }^{1}$ It is obvious that the changes and human losses resulting from these events were such that they could not have remained unnoticed in society (see, e.g., RahiTamm 2005: 29, 41; 2007: 33). At the same time, this was not a subject of public discussion in the post-World War Soviet Estonia. At the end of the 1980s, there were increasing attempts to find opportunities to talk openly about topics that were silenced in the recent history of Estonian society. One of these opportunities was also associated with the life stories collection campaign (Hinrikus \& Kõresaar 2004: 21-23).

During the first decade of the twenty-first century, the consideration of historical themes in life stories was reduced. There were narrators who managed to compress this material into just a short paragraph, as in the following example, taken from the life story of a woman born in 1939:

War. Occupation. Arrests. Battles between the Germans and the Russians on Estonian soil. Communist victory. Executions and mass deportations. The blue-black-white flag replaced by the red hammer-and-sickle flag. (EKLA 350:1:2413)

Topics concerning family matters and close relations became increasingly frequent. A question arose, among others, regarding what kind of relationships had developed between victims of repression or survivors of traumatic events and their descendants. Alongside stories of coping with close relations, there are also examples describing hitherto insurmountable conflicts. In the following excerpt, a woman born in 1986 explains how her grandmother's stories affected her:

She had many stories about Siberia and wartime to recount. She often cried when talking about these issues. I was listening to her and thinking: but my life is also sad, I would like to tell her about my life too. (EKLA $350: 1: 2778)$

It is clear that, in addition to the thematic focal points of life stories, narrator generations had also changed. At the same time, it is possible to feel how the experiences relating to traumatic events of the time (war, repressions) created grounds for the rise of different kinds of traumatic experiences - these relate 
to the self-development of the personality, the changing notions of home, and intergenerational relations. ${ }^{2}$

Estonian memoirs and auto-biographical texts are traditionally considered in the framework of the historical genre. ${ }^{3}$ Thus, the life stories observed here fell within the context of historical narration twice: first, due to the genre, and second, due to the need for the narrators to speak on the topics silenced in the official history.

The preference of life story narrators to speak about the tragic events of the 1940s led researchers to address these stories as "trauma life stories" (Anepaio 2001; Hinrikus 2003: 191-198). However, in these approaches, the described historical events, rather than the manner in which they were depicted, were taken as the basis of definition. When life story researchers began to study the same texts following the approach of trauma theory, they reached the conclusion that these life stories did not use the trauma language familiar in North American literature and trauma culture (Kirss 2002; 2006; Kurvet-Käosaar 2008; Laanes 2017).

Trauma theory was based on portrayals of the Holocaust, and later also on other political conflicts and natural disasters, in which contemporary values play an important role in the interpretation of these events (Leydesdorff et al. 2014 [1999]; LaCapra 2014 [2001]: xxix-xxx, 83-92; Rothe 2011; Meek 2015). Values originating from the time of narration are in the foreground in the stories observed here too, although the highlighted events are of the past. At the same time, one must agree with the above-mentioned observation of life story researchers that the trauma caused by historical events and their aftereffects remain hidden here. Furthermore, the narrators do not use a wording that indicates trauma.

Literature scholar Tiina Kirss has, in the context of the foregoing, directed attention to methodological aspects of researching life stories. She points out that story-mediated personal trauma does not dovetail with an understanding of traumatic experience derived from trauma theory. Trauma theory rather offers an interpretive template that can become a 'controlling interpretation'. For this reason, Kirss directs life-story researchers to take a critical look at the concept of trauma (Kirss 2006: 617). The kind of life-story research in which the study begins with the reading of stories is well-suited to the folkloric approach. Taking what is read as a departure point, new avenues of appropriate interpretation (including those from the researcher's point of view) can be chosen. One direction in trauma theory is associated with the study of general, cross-cultural suffering. For example, Eneken Laanes has applied this approach in the treatment of Estonian biographies (2017). In the folkloric study of life histories, it is more 
fruitful to apply principles that consider the framework of the time and place of the narrative as well as the cultural conventions. Each presentation (text) can be considered as one version of the same story, which is subordinate to the so-called mental text, i.e., depending on the narrator's knowledge and skills of storytelling (Honko 1998: 92-99). Thus, each presentation (text) contains cultural schemas of storytelling (cf., e.g., Neklyudov 1998). Incorporating the concept of trauma into biographical analysis helps to understand the cultural connectivity of trauma expression as well as the transformations of trauma (cf. Balaev 2018).

What then will aid the researcher in delineating the traumatic experience and its presentation in a life story narrative? The notion of cultural trauma, originating from sociology, has proven to be productive in analysing life stories by shaping the material into individual-centred narrative analysis. In defining cultural trauma, essential aspects include both the events causing the upheaval in the society (perceived as negative) and the debates concerning these changes. To access the trauma, researchers look at changes in collective identity (see, e.g., Aarelaid-Tart 2006: 41-48; Debs 2013: 480; Meek 2015: 4-5.) Historian Dominick LaCapra also highlights the shattering of self-image as a characteristic of the trauma experience. At the same time, he stresses the intensity of the impact of such trauma, which makes it difficult to keep under control and nearly impossible to overcome completely (LaCapra 2014 [2001]: 41). Sociologists stress, however, that the case of culturally shared trauma is a social construct that cannot be approached in the same way as the concreteness of individual trauma. This is the same aspect that Kirss pointed out, as was discussed above. The notion of cultural trauma thus suits the life story analysis methodologically: it is possible to start from upheavals that change the narrator's self-image, and the discussion originating from these experiences. One may ask to what extent the cultural trauma embedded in society's collective identity (which is, as sociologists claim, a construct) overlaps with the traumatic experience of the life story narrator and its presentation in the life story. It is obvious that although the life story narrator represents a community carrying a certain collective identity, individual and collective identities overlap only partially. These - the individual trauma and the trauma discussed in society - are mostly connected in the life story narration by a certain relation; for instance, the narrator links his or her story with a certain publicly mediated narrative (Jaago 2018). Therefore, the individual narrative - the life story - is not a miniature image or illustration in relation to society's culture trauma. Collective cultural trauma and individual trauma experience are intertwined but still independent phenomena in life stories. 


\section{LIFE STORY ANALYSIS}

The following analysis of stories first introduces the ways of expressing traumatic experience through the eyes of the event participant. The question raised here is as follows: to what extent and in what way do narrators portray their fears and the feelings of danger they experienced in the past, in the 1940s. Other examples are drawn from narrators who are the offspring of the eyewitnesses. In these stories, the after-effects of the events of the 1940s are revealed through family relations. The analysis of these stories considers how the narrators interpret the issues occurring in close personal relationships, considering what happened to their parents or grandparents during these revolutionary historical periods. From this analysis, a correlation between the manner of narration and the presence or distance of the first-person narrator in relation to the depiction becomes visible. From the development of traumatic experiences and the manner of coping with them, the meaning of home and the presence of the loved ones also emerge.

\section{The war: Events, experiences, rumours}

A woman born in 1912 describes the Second World War, when the frontlines were in their back garden:

During the turmoil of war, the children, together with my paralysed mother, were trapped on the frontline between Russian and German troops at Kabina, alongside the Emajõgi River. My elder daughter Silvi was 6, and Sirje was 2. People said [emphasis added] that local people had been killed and children impaled. ${ }^{4}$ Domestic animals and poultry had fallen prey to the troops; even dogs were given no mercy. (EKLA 350:1:2414)

This episode is important in describing her fear for the family. However, it is a rumour that contains extreme feelings and strong emotions. It is noteworthy that when a person is describing extreme situations that they have just experienced, the narrative is laconic and emotionless. For instance, a woman born in 1924 into an Estonian family in Leningrad writes about everyday life in her hometown during the first winter of the Second World War. She uses simple sentences that contain only factual information and reveal nothing about her mood or feelings.

We brought water from the Neva River. The river was frozen over. But the hole in the ice to get the water was always open. Sailors took care to 
keep the hole open. ... There were also human corpses around the hole. A corpse was pulled aside and the next person took water. There were quite a number of dead bodies. People went to take water, some with a bucket, but most with kettles or pots. (EKLA 350:1:1857)

In situations where people have suspicions or fear of something terrible or horrifying, horror stories and rumours emerge. An example of rumours that spread in the mid-1940s, after the war, in particular in connection with Tartu, are the so-called 'sausage factory' stories. These stories describe sausage factories that were established in the ruins and were said to have used human flesh to make sausages. These stories, their spread and social background, are analysed by folklorist Eda Kalmre (2013) in her monograph The Human Sausage Factory. A Study of Post-War Rumour in Tartu. It should be noted, however, that only a few references to this topic can be found in the life stories. One storyteller, for instance, asks whether such stories could really have had any connections with reality. Working as a police officer during the Soviet period, he had access to documents in which he looked for records of cases where the flesh of people that had disappeared had been used as food. He did not find any records of such cases (EKLA 350:1:1077). In general, drastic situations are related to the stories of others, not themselves. For example, according to one narrator, during the famine resulting from the Leningrad blockade everything was eaten; oiled engine belts, wallpaper, and dandelions were mentioned, but not dogs or cats (EKLA 350:1:1857). When another narrator describes the famine of refugees from Leningrad, she talks about how the refugee family ate a cat (EKLA $350: 1: 1807)$. While the narrators of both biographical stories imply to their reader that they were witnesses to the situation described, it may be noted that usually the narrator does not claim personal involvement in particularly drastic things, but they may claim the involvement of others when they narrate someone else's story. When depicting drastic occurrences, a life-story narrator can easily veer into gossip and urban legends. These help to characterize the circumstances and mindset of the epoch being described in an impersonal way. However, rumours and urban legends in biographical narratives are viewed with caution by researchers, as they are not authoritative texts in the context of studying history in the Estonian cultural space.

The horror rumours appear in stories that actually start with the words "It is said that...", or now, retrospectively, "It was said that...". The stories are related to the function of situational assessment or warning the community. Thus, such horror stories allow the study of situations that caused stress in society (e.g., in the 1940s, fear for children, disappearance of people, lack of food and related concerns). However, the function of the rumours changes quickly 
(in this case, for example, horror stories change over time into stories describing the atmosphere during and after the war, or into amusing stories or just falsehoods that cause misunderstanding). The dynamic function of rumours is one of the reasons why the connection of rumours with traumatic experience may not be noticed by the life story researchers.

\section{Parents and children}

Analysis of the Estonian Life Stories Collection has revealed that in the stories of people born before the 1950s, parent-child relations are depicted as being predominantly positive (Kõresaar 2002). The situation is different in the stories of people born in the 1950s (Jaago 2003). On the one hand, relations with parents weaken, since they either have long workdays or children live apart from their parents, with their grandparents, for example. On the other hand, it becomes clear that parents do not talk about the events of the 1940s. This is because of safety considerations for the children as well as fear of political repression. I asked a life story narrator born in 1934 to discuss the meaning of family and the change in this meaning. Her father was also in a Stalinist prison camp, and in her life story she describes the hardships this situation caused her as well as her mother and siblings. But she does not describe the conflict stemming from the repression in family relations. She answered my questions in the following way:

We grew up in a family that still had strong pre-war Estonian influences and we had three families in the same yard.... What a child must do and cannot do, that was made clear by my mother, and sometimes she was short-tempered indeed: we were tweaked by the hair and in the event of bigger mischief, we also got the birch. After the punishment was received, the sky was clear again... When unstable times messed up the world order, a decent home was "a safe haven". ... Perhaps contemporary times have diminished the meaning of home: parents, even if they are with their family, concentrate on their own lives, and children strive to handle the rights of "grown-ups" before their time, at the same time giving up the responsibilities of adults. (MK: EKLA 350:1:1120, e-mail 2018)

I was amazed both by this woman's biography and the quoted e-mail about what was said regarding the punishment of children. The physical punishment of children, in particular, is one of the important things that post-1950s biographers present in their stories as a traumatic experience. But in this story of a woman born in 1934, the physical punishment of children has no connection with traumatic experience. 
At the same time, her story emphasizes the common responsibilities of children and parents in the formation of the family, which is not found in the stories of those born in the post-war years.

It can thus be said that trauma is not caused by any particular phenomenon, such as the physical punishment of children. The analysis of the traumatic experience must be based on the relationship pattern presented in the biography as a whole. How did the relationship between the imprisoned parents and their children develop when the imprisonment was over? In the story of the narrator quoted above, this relationship is also shaped by the responsibility for the wellbeing of family members, as she stated in her email. "We grew up in a family that still had strong pre-war Estonian influences," she wrote.

There are, however, other examples of how parents with a traumatic past were experienced by their children. This subject caught my special attention after I made contact with two daughters of life story narrators. Both life story narrators had ended up in prison camps: one of them, a woman born in 1918, who was detained in a Nazi camp, while the other, a woman born in 1923, was in a Stalinist prison camp (EKLA 350:1:405; EKLA 350:1:444). Both stories were written in 1996-1997. I met both of the authors and analysed their stories in more detail (Jaago 2004; 2012; 2018). The daughters of both life story narrators (one of them born in 1938, the other in 1953) expressed long-lasting conflicts with their mothers (MK: EKLA 350:1:405, fieldwork report 2018; MK: EKLA 350:1:444, e-mails 2017). Although neither of these women speaks about the conflict in their life story narrations, the stories told by their children highlight how difficult it was for their mothers to cope with close relations postimprisonment. But in both cases, another aspect is important. Namely, both daughters were separated from their mothers at an early age: one due to her mother being in the prison camp, and the other due to post-camp illness. This last aspect in particular begs the question of the extent to which the separation shaped the aforementioned conflicts.

The following life story examples are selected from those told by narrators born after the war and mass repressions. The narrator of the first story grew up at home, while the other was separated from her parents during childhood. The question is whether, how, and to what extent the war and Stalinist repressions are reflected in these stories.

The first example is chosen from among the contributions received in the 2016-2017 collection campaign "Estonia 100. My life and love" (EKLA 350:1:2657). ${ }^{5}$ The author of this 13-page story is a woman born in 1957. She begins her story with words once said to her by her mother: "You should not have been born." The narrator explains her ambivalent feelings relating to this: initially shock, hints of difficult relations with her mother, but later a broader 
realisation, followed by an understanding of her mother. There are three subthemes that serve as anchor points for her story: the house that her father built, which "has influenced both my mother's and my own choices"; predestination or fate ("I believe in fate and think that everything is written in the stars"); and the Second World War and Soviet imprisonments ("yes, I was born 13 years after the war ended, but the preconditions of my birth were still created in the turmoil of war").

The war led to her parents' first meeting: they happened to hide from the battles in the same forest. "This was how two people that were not supposed to meet met." They married in order to cope better with the situation that had developed, but the daughter says: "They were certainly not meant for each other." The man "was taken to Vorkuta for 12 years" and the woman was left with a 4-month-old son. This was the post-war period, when many women raised their children alone. The narrator indicates the general attitude of that time through the words of one of her mother's teachers: "During a lesson, a male teacher said that nothing good would come of sons who grew up without a father!" Influenced by these words, the mother raised her son "super properly", where a part of the upbringing included beatings, as the narrator stresses.

During this period, the narrator's mother met "the love of her life". But a little later he was imprisoned too. While both her husband and "the love of her life" were in prison, a third man, the so-called "romantic musician", entered her life. This encounter did not end in family life, but with a little boy, the narrator's half-brother. "The love of her life" returned from prison, but family life did not work out. As a reason, the narrator presents this little boy whom the man did not recognize as his. And the mother did not care about the narrator's father. "Father came home on the night of 24 February $^{6}$.... When they heard the knock, the older son said: "Open the door, it's Father!" At that time, nighttime knocks on the door were dreadful". Father started building the house and mother "liked the man who built her a house". Neither "the love of her life" nor the musician were "house builders". Into this house, a girl was born, the narrator of this story, and "now here in this house I sit, write and freeze".

The previous quotations show what and how she was told about the events in the 1940s and 1950s: she knows about seeking shelter in the forest, the nocturnal arrests ("at that time, night-time knocks on the door were dreadful"). By the time of her birth at the end of the 1950s, the situation and relations had become clear: her father was back from prison and was building a house; the family was together despite the twists of the intervening years. But it appears that all the preceding events somehow remained in their lives and started to influence the child who was born after the events previously described. 
Her childhood was happy, she claimed. But fear was nevertheless a part of it too, because people told stories about war and prison. "I often saw war in my dreams, and when I woke up, I was immensely happy if I could see the blue sky and green birch tops from the window." A fear of night-time arrests was also a part of her childhood, as well as loud bangs, which were reminiscent of bomb explosions. She also describes sandbox games with her brother. It appears they built prisons instead of sandcastles, "the inescapable kind".

She did not develop close relations with her (biological) brother, who was 14 years her senior. Her half-brother was a playmate during childhood, but relations cooled in adulthood. "This boy had a tough childhood - he had to work a lot and was sometimes beaten." The issue of beating children emerges once more, being a part of the upbringing of the time. The mother beat the older son so that the fatherless boy (in defiance of the male teacher's words) would still grow up to be a decent person. The other son received beatings from both parents. The narrator - a girl - was not beaten though. "When I misbehaved, pointing to this [the belt] was enough." About herself as a mother, she writes: "The children cried a lot at night. I was jittery and screamed, sometimes I hit them. Yet I loved my children a lot. ... And I will feel forever guilty for hitting them and pulling their hair. The children have forgiven me; I myself not yet." This story brings into view a pivot point between the childrearing methods of parents and their children. While for her parents beating a child as a means of punishment was natural and presumably efficient, for her generation it is no longer so. The problem for the narrator, however, lies in the fact that she also applied this method of childrearing herself when raising her children. However, now she regrets this.

But what is peculiar to this story? In contrast to the aforementioned relationships between daughters and their formerly imprisoned mothers, she describes the hardships that she faced when communicating with her mother, but she describes this through understanding, not through conflict. During the final period of her mother's life they were living together, and the daughter writes: "A difficult life began, incomprehensible to me." She seems to be closer to her father. Yet she knows her mother: she not only knows her life history but can also describe her mother's feelings and reasons for her choices. She learned about them from her mother and understood them. It can be surmised that she views her mother empathetically: as a narrator, she is not only a daughter but also a woman and a mother herself. In this way, this is certainly a story of contradictory feelings - but also a story of love.

The second example is from a 13-page life story contributed to the same collection campaign, narrated by a woman born in 1986 (EKLA 350:1:2778). 
It appears from her life story that contact between her, her grandmother, and her parents is missing. Even if they speak about their experiences, it does not create a sense of unity. Rather, it seems that they do not understand or even listen to each other. Near the beginning of the story she claims: "Unfortunately, I have to admit that my parents did not love me." Then she stresses she has "grown up without love, without a father or mother, without sisters or brothers".

The previous story focused on trauma experiences that were linked to family relationships as well as the fear that was characteristic of that time. Traumatic experiences that the author deliberately dealt with were expressed. The following story contains a trauma that can be described as a lack of love. It is a traumatic experience, as the narrator perceives it. The narrator believes that love as a definite phenomenon exists somewhere for her - if she seeks, she will find it. The reader, however, understands that she cannot find it, because she has not experienced how love is created through intimate relationships. It appears her parents were alcoholics and that she grew up in an orphanage or in foster families. Although she describes life in a foster family being like the life of those who grew up with their parents, she does not develop trust in the foster parents. Actually, she did have a real sister and a grandmother, but she did not develop close relationships with them. Here, one important aspect relating to love unfolds: its existence in childhood and adolescence ensures the possibility of creating love on one's own and being ready for it. Although love brings along the pain of loss, it is still important in coping with the creation and shaping of new relationships. However, a bitter experience emerges from this narrator's story: in her imagination, love still exists for her somewhere, and she has not given up her search for it. But since she did not experience love in her childhood, she is unable to recognize and create this feeling. Traumatic experiences come to the fore in her story. She experienced violence in her foster home. She has been in contact with her alcoholic father. She feels that her sister has betrayed her and her grandmother does not care about her. She wishes to achieve closeness which she has missed all her life. But all her attempts to get close to someone fail.

The narrator of this story shifts the primary feeling of lack in her story to relations between the mother and her children. It appears her mother also grew up in an orphanage and had to somehow manage on her own, without the support of close relatives. "These hardships were probably the reason why mother started drinking, and in the end, she was unable to stop it." It turns out that her mother had eight children who ended up in an orphanage. As a result, the narrator's story shifts toward the Estonian state (bearing in mind the topic of the life story collection competition: "Estonia 100. My life and love"). She expects some kind of action from the state so that there would no longer 
be such mothers unable to manage their lives. Specifically, she does not call for support for these types of mothers, but instead calls for the state to make sure that women like that would not become mothers. In this way, her story is also reduced to a discussion about a mother's role in the development of her child's life and well-being. However, in contrast to the previous story, there is no empathy connecting the mother and daughter in this story.

\section{CONCLUSION}

The life stories narrated in the 1990s in the main highlighted what happened in the 1940s and how these revolutionary historical-political events changed people's fate and identity. Researchers have also treated these narratives as traumatic life stories, because the events depicted in the narratives are presented in the context of Estonian history. This historical picture tells the story of the losses of the Estonian people (loss of national independence, destruction of homes, imprisonment of close family members, or their loss as a result of being scattered all around the globe).

Most of the narrators of these stories were also participants in the events described. In the stories of the 2000 s, the narrators' focus shifts: what emerges are the issues of the immediate descendants of the oppressed and the wartorn - those who experienced the vicissitudes of the 1940s on an ongoing basis. The traumatic experiences of those who participated in the events of the 1940s shaped these participants in ways that their children could in turn experience as traumatic. This was due to the complicatedness or even the absence of relationships. The relationship between the person and his or her traumatic experience was manifested in the way the narrators position themselves in their story.

In stories describing historical events, the narrator places herself primarily in the societal position: she must manage political-historical situations such as war, imprisonment, and post-war or post-imprisonment economic difficulty. Individual roles of parents and children emerge in stories describing family relations. The stories that have been considered comprise instances where roles are not switched in personal narrations (e.g. daughter's conflict with mother) as well as those where this happens. In the latter case, the life story becomes multi-layered, and descriptions of confrontations are also augmented by understanding. Despite different foci, it is possible to see that there is a certain connection between these stories.

The more the descriptions of the pivotal periods and first-hand experience of the periods disappear from the life stories, the more we can see how the earlier period changed the society and the patterns of close relationships. While the 
nightmares described in the stories of people born before the war were caused by historical events (the war, Stalinist repressions), the stories of the ones born in post-war years reveal a new pressure. This is characterized by an inability to cope with family relations and close relationships. Such an inability to cope is described in the context of shortcomings in the narrator's relationship with her parents. The narrators refer to the volatility and frustration of their parents, but also to domestic violence, which is now interpreted as a traumatic experience.

In the context of the above, the impact of the time covered by the narration on how the past is described must again be stressed. Today's narrators present their stories in quite a different cultural context as compared to their parents in the 1990s. While at that time, people were interested in the historical events and situations that the Soviet approach to history did not discuss, today's public sphere (e.g. mass media) brings to the fore the topics of family relations and everyday interpersonal relationships. This reveals the interconnection between storytelling and interpretation of the past: the roots of today's problems lie in the recent past, covering two or three generations.

\section{ACKNOWLEDGEMENTS}

This research project has been supported by the Academy of Finland (as part of the project "Traumatized Borders: Reviving Subversive Narratives of Borders, and Other", SA 297533), and by the Estonian Research Council ("Vernacular Interpretations of the Incomprehensible: Folkloristic Perspectives Towards Uncertainty", PRG670).

\section{NOTES}

1 For life trajectories of the youth of Estonian origin during the Second World War, when Estonia was either a part of the Soviet Union (1940-1941, 1944 onwards) or occupied by German forces (1941-1944), see, e.g., Soldiers of Memory, a collection of articles and life stories compiled by Ene Kõresaar (2011).

2 In her analysis of the traumatic experience of the descendants of Holocaust survivors, Carol A. Kidron (2003) offers a parallel to the question raised here, asking how the traumatic experience affects the survivors' children, despite the fact that the situation itself, which caused the trauma, has been left behind.

3 This trend connected Estonia with the Central European literary tradition, where until the last quarter of the twentieth century, history-centred narration belonged primarily to the French and German tradition, while the literary narration of memoirs was a feature of Anglophone culture (see Haan \& Renders 2013: 18-22). 
4 Impalement of children during war is a familiar trope in Estonian folklore, seen, for example, during the period of the Great Northern War in the early eighteenth century.

5 The life stories sent as a response to the collection campaign "Estonia 100. My life and love" have been published partly in the book Minu elu ja armastus. Eesti rahva elulood (My life and love. Estonian life stories) in 2018, edited by Rutt Hinrikus and Tiina Ann Kirss. The life stories observed in this article have not been selected for this publication.

6 The anniversary of the Republic of Estonia is 24 February, but this was obviously not celebrated openly in Soviet Estonia.

\section{ARCHIVAL SOURCES}

EKLA 350 - manuscript collection of the Estonian Life Stories, Cultural History Archives, Estonian Literary Museum

MK - fieldwork materials collected by Tiiu Jaago, Department of Estonian and Comparative Folklore, University of Tartu

\section{REFERENCES}

Aarelaid-Tart, Aili 2006. Cultural Trauma and Life Stories. Helsinki: Kikimora Publications. Available at https://helda.helsinki.fi/bitstream/handle/10138/23467/ cultural.pdf?sequence=2, last accessed on 3 June 2021.

Anepaio, Terje 2001. Trauma ja mälu. Mineviku ületamisest represseeritute kogemuses. [Trauma and Memory: Repressed Estonians Coping with Past.] In: Terje Anepaio \& Ene Kõresaar (eds.) Kultuur ja mälu. [Culture and Memory.] Studia Ethnologica Tartuensia 4. Tartu: Tartu Ülikooli Kirjastus, pp. 198-215. Available at https://dspace.ut.ee/handle/10062/54450?show=full, last accessed on 3 June 2021.

Balaev, Michelle 2018. Trauma Studies. In: David H. Richter (ed.) A Companion to Literary Theory. Oxford: Wiley Blackwell, pp. 360-371. https://doi. org/10.1002/9781118958933.ch29.

Debs, Mira 2013. The Suffering of Symbols: Giotto Frescoes and the Cultural Trauma of Objects. Cultural Sociology, Vol. 7, No. 4, pp. 479-494. http://dx.doi. org/10.1177/1749975512454086.

Haan, Binne de \& Renders, Hans 2013. Towards Traditions and Nations. In: Hans Renders \& Binne de Haan (eds.) Theoretical Discussions of Biography: Approaches from History, Microhistory, and Life Writing. Lewiston \& Queenston \& Lampeter: Edwin Mellen Press, pp. 15-33.

Hinrikus, Rutt 2003. Eesti elulugude kogu ja selle uurimise perspektiive. [The Collection of Estonian Life Stories and the Perspectives of Its Study.] In: Arvo Krikmann \& Sirje Olesk (eds.) Võim ja kultuur. [Power and Culture.] Tartu: Eesti 
Kirjandusmuuseum \& Eesti kultuuriloo ja folkloristika keskus, pp. 171-213. Available at http://www.folklore.ee/ kriku/TRANSPORT/RAAMAT_EKM.pdf, last accessed on 3 June 2021.

Hinrikus, Rutt \& Kirss, Tiina Ann (eds.) 2018. Minu elu ja armastus. Eesti rahva elulood. [My Life and Love. Estonian Life Stories.] I-II. Tallinn: Tänapäev.

Hinrikus, Rutt \& Kõresaar, Ene 2004. A Brief Overview of Life History Collection and Research in Estonia. In: Tiina Kirss \& Ene Kõresaar \& Marju Lauristin (eds.) She Who Remembers, Survives: Interpreting Estonian Women's Post-Soviet Life Stories. Tartu: Tartu University Press, pp. 19-34.

Honko, Lauri 1998. Textualising the Siri Epic. Folklore Fellows' Communications 264. Helsinki: Academia Scientiarum Fennica.

Jaago, Tiiu 2003. Popular Narrative, Cultural Continuity and Changing Political Regimes. Journal of Indian Folkloristics, Vol. 5, No. 1-2, pp. 97-108.

Jaago, Tiiu 2004. 'It was all just as I thought and felt': One Woman's World in the Context of 20 th Century Events. In: Tiina Kirss \& Ene Kõresaar \& Marju Lauristin (eds.) She Who Remembers, Survives: Interpreting Estonian Women's Post-Soviet Life Stories. Tartu: Tartu University Press, pp. 144-165.

Jaago, Tiiu 2012. Cultural Borders in an Autobiographical Narrative. Folklore: Electronic Journal of Folklore, Vol. 52, pp. 15-38. http://dx.doi.org/10.7592/FEJF2012.52. jaago.

Jaago, Tiiu 2018. Trauma ja elulood. [Trauma and Life Stories.] Mäetagused, Vol. 71, pp. 111-142. https://doi.org/10.7592/MT2018.71.jaago2.

Kalmre, Eda 2013. The Human Sausage Factory. A Study of Post-War Rumour in Tartu. Amsterdam \& New York: Rodopi.

Kidron, Carol A. 2003. Surviving a Distant Past: A Case Study of the Cultural Construction of Trauma Descendant Identity. ETHOS: Journal of the Society for Psychological Anthropology, Vol. 31, No. 4, pp. 513-544. http://dx.doi.org/10.1525/ eth.2003.31.4.513.

Kirss, Tiina Ann 2002. Põgenemine ja trauma. [Escape and Trauma.] Looming, Vol. 12, pp. 1870-1880. Available at https://www.digar.ee/viewer/et/nlibdigar:115407/16375/page/112, last accessed on 3 June 2021.

Kirss, Tiina Ann 2006. Põgenemisteekonnad ja põgenemislood. [Escape Routes and Stories.] In: Tiina Kirss (ed.) Rändlindude pesad: Eestlaste elulood võõrsil. [The Nests of Migratory Birds: Life Stories of Estonians Abroad.] Tartu: Eesti Kirjandusmuuseum \& Toronto Ülikooli Eesti õppetool, pp. 611-646.

Kõresaar, Ene 2002. The Farm as the Symbol of the State: Metaphorical Depiction of the Nation and the State in the Childhood Memories of Older Estonians. In: Tiiu Jaago \& Mare Kõiva \& Kairika Kärsna (eds.) Lives, Histories and Identities: Studies on Oral Histories, Life and Family Stories. Contemporary Folklore 3. Tartu: University of Tartu \& Estonian Literary Museum, pp. 169-187. Available at http://lepo.it.da.ut.ee/ lehti/Oralhistory/2.2.Ene.html, last accessed on 3 June 2021.

Kõresaar, Ene (ed.) 2011. Soldiers of Memory: World War II and Its Aftermath in Estonian Post-Soviet Life Stories. Amsterdam \& New York: Rodopi. 
Kurvet-Käosaar, Leena 2008. Vaikusesse vajunud aeg. Naise traumaatiline repressioonikogemus Imbi Paju dokumentaalfilmis ja raamatus Tórjutud mälestused. [Time That Has Sunk into Silence. Woman's Traumatic Experience of Soviet Repressions in Imbi Paju's Memories Denied.] Ariadne Lõng: Nais- ja Meesuuringute ajakiri, Vol. 1/2, pp. 136-147, 164-165. Available at https://www. enut.ee/files/ariadne_long_2008.pdf, last accessed on 3 June 2021.

Laanes, Eneken 2017. Trauma keelde tõlgitud. Kultuurideülesed mäluvormid eesti laagri- ja küüditamismälestustes. [Translated into the Language of Trauma: Transcultural Patterns of Memory Observed in Estonian Memoirs of the Gulag and Deportation.] Keel ja Kirjandus, Vol. 4, pp. 241-257. Available at https://www. utkk.ee/wp-content/uploads/2020/01/trauma-keelde-tolgitud.pdf, last accessed on 3 June 2021.

LaCapra, Dominick 2014 [2001]. Writing History, Writing Trauma. Baltimore: Johns Hopkins University Press.

Leydesdorff, Selma \& Dawson, Graham \& Burchardt, Natasha \& Ashplant, T.G. 2014 [1999]. Introduction: Trauma and Life Stories. In: Kim Lacy Rogers \& Selma Leydesdorff \& Graham Dawson (eds.) Trauma and Life Stories: International Perspectives. Routledge Studies in Memory and Narrative. London \& New York: Routledge, pp. 1-26.

Meek, Allen 2015. Cultural Trauma, Biopolitics and the Limits of Responsibility. Borderlands, Vol. 14, No. 2, pp. 1-19.

Neklyudov 1998 = Nekliudov, Sergei. Istoricheskii narrativ: mezhdu real'noi deistvitel'nost'iu i fol'klorno-mifologicheskoi skhemoi. [Historical Narrative: Between Reality and Folkloric-Mythological Scheme.] In: Konstantin Vogdanov \& Aleksandr Panchenko (eds.) Mifologiia i povsednevnost'. St. Petersburg: Institut russkoi literatury RAN, pp. 288-292.

Rahi-Tamm, Aigi 2005. Inimkaotused. [Human Losses.] In: Ülo Ennuste \& Erast Parmasto \& Enn Tarvel \& Peep Varju (eds.) Valge raamat: Eesti rahva kaotustest okupatsioonide läbi 1940-1991. [White Book: The Losses of the Estonian People during Occupations in 1940-1991.] Tallinn: Eesti Entsüklopeediakirjastus, pp. 23-42. Available at https://www.digar.ee/arhiiv/et/raamatud/12312, last accessed on 3 June 2021.

Rahi-Tamm, Aigi 2007. Stalinist Repression in Estonia: State of the Research and Open Questions. Croatian Political Science Review, Vol. 54, No. 1-2. Special issue: Faces of Cultural Trauma, pp. 32-51. Available at https://politickamisao.com/ stalinist-repression-in-estonia-state-of-the-research-and-open-questions/, last accessed on 3 June 2021.

Rothe, Anna 2011. Popular Trauma Culture. Selling the Pain of Others in the Mass Media. New Brunswick \& New Jersey \& London: Rutgers University Press. 
Tiiu Jaago

Tiiu Jaago $(\mathrm{PhD})$ is Associate Professor at the Department of Estonian and Comparative Folklore, Institute of Cultural Research, University of Tartu, Estonia. Her main fields of research include older Estonian folksong (figurative language, socio-historical background of song tradition), hereditary history (family histories, folksy views of history, migration, and multicultural experience).

tiiu.jaago@ut.ee 